histones from a single source, the characteristics of histones from different sources, techniques and results of analyses, are fully discussed, making this a useful reference section. The rapid development of this topic is, incidentally, made obvious by the confusion of nomenclature and the plea for a unified system.

The structure of nucleohistones opens with a chapter by Zubay in which he discusses in detail the essential feature of the problem, the function of histones. After a review of the previously published evidence and an exposition of the Jacob-Monod theory of the regulation of protein synthesis, he concludes that most histones are involved solely as structural proteins concerned with the supercoiling of DNA and its availability as a source of information during interphase. It is clear from subsequent papers that, although much has been discovered about the properties of isolated histones, for example the $\alpha$-helix content, the nature of their interactions with DNA is relatively unknown.

The remainder of the book is largely concerned with dynamic aspects. In the chapters concerned with histone metabolism results of turnover investigations lead several authors, for example Dounce et al. and Busch etal., to the conclusion that specificity requirements for gene inhibition cannot be met by the histones. In the following section on enzymology the control function of the histones is further discussed. Huang and Bonner, and Allfrey and Mirsky, report experiments showing that histones inhibit DNA-primed RNA synthesis, thus providing experimental evidence for the Stedmans' inhibition hypothesis, while Billen and Hnilica have shown some specificity of inhibition of DNA synthesis in vitro by different histone fractions.

The role of histones in development covers examples of function in one cell cycle and aspects of differentiation. The problem of specificity is raised again by Bloch, as a consequence of his conclusion that probably any histone could combine with any DNA, and by Zalokar, who considers that removal of histone from incompetent genes does not make the genes active but makes them susceptible to the action of inducers.

The last section of the book is entitled "Thoughts for the Future", and in five chapters the various authors speculate on the developments as they see them. This will be to many readers the most thought-provoking section. In a final chapter the editors set out in a logical sequence the various possibilities for histone behaviour within the cell and discuss specific experiments designed to test them. This forms an elegant essay demonstrating the way in which to decide on the information required from an experiment and how to approach the interpretation of results.

The reader will have realized that this review does not do justice to all the authors. By mentioning the points raised by a few of them an attempt has been made to illustrate the coverage of the work. It will be apparent that although a great deal is known this has mainly resulted in a realization that the structure and functions of histones is a more complicated problem than was thought a decade ago.

A. R. Crathorn

\section{KARL POPPER'S CRITICAL RATIONALISM}

The Critical Approach to Science and Philosophy Edited by Prof. Mario Bunge. (Essays in Honor of Karl R. Popper.) Pp. xv +480. (New York: The Free Press of Glencoe, a Division of the Macmillan Company; London: Collier-Macmillan, Ltd., 1964.) n.p.

KARL POPPER is a philosopher who, during a period K of philosophical disillusionment-a "time of drought", as Karl Löwith has called it-has had the courage to put forward a comprehensive view that has relevance for most of the branches of philosophy as well as for mathematics and the natural sciences and for history and the social sciences. His view was first presented in Die Logik der Forschung in 1934, where he argued that scientific theories are not established inductively but must be regarded as hypotheses-he later used the term "conjectures" - which hold the field so long as they have not been shown to be false when put to the test.

Theories are not established or verified, but withstand or fail to withstand attempts to refute them, so that the path to truth is through the rejection of error. In subsequent writings, notably in the Poverty of Historicism, which appeared in Economica in 1944, and in The Open Society and its Enemies published in 1945, Popper developed his non-inductivist, non-verificationist view into a general defence of rational criticism in opposition to the methods of dogmatism and authority. He argued that in morals the prevention or lessening of suffering takes precedence over the production of happiness, and gave reasons for preferring piecemeal reform to total planning. Like Comte, Popper holds that science and morality are closely interlocked though not identical, but, unlike Comte, he holds that large-seale prediction of the future of society is in principle impossible.

This collection of essays in his honour is divided into four parts. Part 1 contains eight essays under the general heading of "The Critical Approach to Philosophy". Of these we may specially notice the first, in which W. W. Bartley III argues that Popper's critical method implies the inadmissibility of any attempt to 'justify' a theory, or, I suppose, a belief, practice or institution. For justification, according to Bartley, requires an appeal to some ultimate authority, whereas criticism, with its reliance on falsification, needs no such extraneous support. Paul Bernays, in a paper entitled 'Reflections on Karl Popper's Epistemology", while in agreement with Popper's main tendency, suggests that testing is not such a pessimistic thing as Popper assumes when he takes it as the attempt to overthrow the conjecture being tested. Bernays's critical examination of testing and of criticism itself is brief but fruitful. Part 2 contains four essays under the general heading of "The Critical Approach to Logic and Mathematics". We may here note W. C. Kneale's defence, against Popper, of the view that the necessity of laws of Nature is similar in kind to the necessity of laws of logic. There are other papers on logic by $\mathbf{H}$. $\mathbf{B}$. Curry, N. Rescher and G. Stahl. Part 3, entitled "The Critical Approach to Science", contains twelve papers. Feierabend criticizes instrumentalism and incidentally discusses the quantum theory, as does O. R. Frisch in a paper on that subject. A. Grünbaum, in a paper on irreversibility, criticizes Popper's view, stated in Nature in 1956,1957 and 1958 , that the 'arrow of time' is not closely connected with and not dependent on the law of entropy. Popper's and Kneale's views on natural necessity are briefly discussed at the end of Yourgrau's paper on the reality of elementary particles. The fourth part of the book is called "The Critical Approach to Society and History", and of the five essays that make it up we may mention Pieter Geyl's appreciative review of Popper's Open Society. The book concludes with a bibliography of Popper's writings.

There is, of course, plenty of support for Popper in this volume, but it is far from being a collection of laudatory testimonials. In some of the papers he is not discussed at all, and in others, as we have seen, he is honoured by being criticized. He is also honoured by the galaxy of talent who have contributed to the book, for it is a tribute to the interest that his views have aroused, as well as to the skill of the editor, that space only allows me to mention contributions by Gombrich and by Hayek and forces me to leave many others unmentioned altogether.

H. B. ACTON 